\title{
ХУДОЖЕСТВЕННЫЙ КОНЦЕПТ „ВЕНЧАНИЕ” В ПОВЕСТИ И.А. БУНИНА ДЕРЕВНЯ
}

\author{
THE SEMANTIC CONTENT OF THE CREATIVE CONCEPT \\ OF "THE SACRAMENT OF MATRIMONY" \\ IN IVAN BUNIN'S SHORT NOVEL THE VILLAGE
}

\author{
NATALIA KRÓLIKIEWICZ
}

\begin{abstract}
To understand the semantic content of the creative concept of "the sacrament of matrimony" in Ivan Bunin's novel The Village, it is necessary to focus on revealing the semantic components of "culture coagulate" (a term by J. Stepanov) and its artistic realization on various levels of the text. This analysis allows the author to indicate that opposites (such as death and birth, wedding and funeral, tragedy and farce) are united in a way that is typical for Bunin.
\end{abstract}

Natalia Królikiewicz, Uniwersytet im. Adama Mickiewicza w Poznaniu, Poznań - Polska,n.krolikiewicz@tlen.pl

Попытка приблизиться к пониманию смыслового содержания художественного концепта „венчание" в произведении одного из самых значительных русских художников XX столетия, Ивана Бунина, обосновывает необходимость в данной статье сконцентрироваться на раскрытии семантических компонентов названного „сгустка культуры" 1 (термин Ю.С. Степанова) и его художественного воплощения на разных уровнях (тематическом, сюжетно-композиционном, образном) бунинского текста. При этом ставится задача показать глубину онтологического осмысления писателем русской жизни, ее изначальных духовно-нравственных основ, связанных с православным миропониманием и мифопоэтическим мироощущением.

При расмотрении самого понятия концепта как основной единицы когнитивной деятельности необходимо подчеркнуть, что это понятие стало объектом пристального внимания разных научных дисциплин: когнитивной лингвистики, лингвокультурологии, литературоведения, психолингвистики и др. Тенденция к междисциплинарности, характеризующая современную научную парадигму, а также реализация целей данной статьи предполагают выбор определенной мето-

1 Ю.С. С т е п а н о в, Константы. Словарь русской культуры. Опыт исследования, Москва 1997, с. 40. 
дологии, содержащей элементы как лингвокультурологического, так и литературоведческого анализа. Раскрывая отражение названного художественного концепта (отличающегося от познавательного своей творческой природой, поэтической ассоциативностью и заключающего в себе потенцию к раскрытию образов) в бунинской повести, мы воспользовались работами таких философов и ученых, как Михаил Бахтин, Юрий Лотман, Алексей Лосев, Дмитрий Лихачев, Юрий Степанов, Нина Арутюнова, Виктория Захарова, Ольга Сливицкая, Алексей Пискулин, Эрна Померанцева и др.

Впервые термин „познавательный концепт” был введен русским философом С.А. Аскольдовым, определившим его как мысленное образование, которое замещает в процессе мысли неопределенное множество предметов одного и того же рода ${ }^{2}$. Каждый человек имеет индивидуальный культурный опыт, запас знаний и навыков, которыми определяется обилие значений слова и концептов этих значений. Чем у́же культурный опыт человека, тем беднее не только его язык, но и „концептосфера” (термин введен литературоведом Д.С. Лихачевым) его словарного запаса - как активного, так и пассивного ${ }^{3}$. Концепт - это результат столкновения словарного значения с опытом человека. Концепт существует для каждого отдельного словарного значения слова. Какое именно из значений актуализируется, замещается, зависит прежде всего от контекста или ситуации общения 4 . Интересным может показаться тогда сравнение с аналогичной идеей М.М. Бахтина о возможности раскрытия одного смысла только в процессе диалога с другим, изоморфным ему смыслом ${ }^{5}$. Следовательно, концепт расширяет значение слова и оставляет возможность домыслить, создать эмоциональную атмосферу.

Среди культурологов наиболее активно и плодотворно исследовал концепты С.Ю. Степанов, определяя концепт как „сгустки культурной среды в сознании человека”, подчеркивая, что „концепты не только мыслятся, они переживаются" 6 . В концепте всегда есть составляющие, которыми он и определяется, т. е. имеется шифр ${ }^{7}$, который, как замечает Н.Д. Арутюнова, образует культурный слой, являющийся мостом

2 С.А. А с к о л ь д о в, Кониепт и слово, [в:] Русская словесность. От теории словесности к структуре текста. Антология, ред. В.П. Нерознак, Москва 1997, с. 251.

3 Д.С. Л и х а ч е в, Концептосфера русского языка, [в:] Русская словесность..., указ. СОч., с. 282.

4 Там же, с. 287.

${ }_{5}^{5}$ М.М. Б а х т и н, Проблема речевых жанров. Проблема текста, [в:] его же, Собрание сочинений 85 томах, т. 5, Москва 1996, с. 206.

${ }^{6}$ Ю.С. С т е п а н о в, указ. соч., с. 427.

7 Б. Р а с с е л, История западной философии, т. 1, Москва 1993, с. 368. 
между человеком и миром. Исследователи в настоящее время сходятся во мнении, что концепты являются единицами сознания, отражающими человеческий опыт в форме той или иной информационной структуры. Структурная организация концепта, подразумевающая содержание в нем трех слоев 8 , предполагает наличие его буквального смысла (этимологии), а также основных и дополнительных компонентов (обнаруживая тем самым аксиологические доминанты).

Анализируя концепт „венчание”, следует отметить этимологическую основу данного понятия (от венчать, венеи), отсылающую нас к христианскому обряду (возможно, существовавшему еще и до принятия христианства9) возложения венца (короны царской) на головы верующих при вступлении их в церковный брак. Само слово „венец”, не только как символ брака в обрядовой семантике, имеет глубокое духовно-символическое значение. Венец - еще в древности был символом победы, поэтому возложение венцов на главы жениха и невесты служит для них как бы наградой за их целомудренную жизнь до брака. Венец - образ солнца (Солнце для православного - Христос), от которого идет и тепло, и свет. Венец - знак чистоты, вследствие чего брачные венцы должны заключать в себе чистоту и доверчивость детства, простоту, дружелюбие, сердечность. В Евангелии от Матфея Господь напутствует: „[...] если не будете как дети, не войдете в Царство небесное"10. И еще один символ видится в венце - терновый венец Христов, образ страдания и мужества, преодоление креста и смерти. Следует заметить, что для христианского Востока именнно венец стал основным символическим действием, которое дало название всему чину - „венчание”. Таким образом, Венчание в Православной Церкви является Таинством (как особое действие Бога через Церковь в мире), то есть местом особой встречи между Богом и человеком, неким импульсом, который дает начало новому вектору в жизни супругов ${ }^{11}$.

Если речь идет об устойчивых семах концепта „венчание”, то среди них можно отметить такие понятия, как жених, невеста, священник, церковный брак, свадебный обряд, таинство, благословение, венчаль-

8 Ю.С. С т е п а н о в, указ. соч., с. 428.

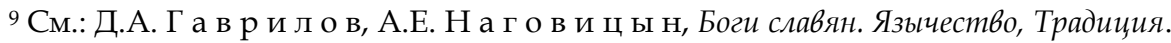
Возможно, что в дохристианские времена знаком принадлежности к любимцам Ярилы, как бога весеннего, покровителя брачующихся, был также венок. Кто дарил девушке венок, становился ее женихом (или девушка, отдавая в качестве „вено" венок, фактически становилась невестой.

10 Матфея 18:3.

11 Протоиерей Владимир Х у л а п, Таинство Венчания, [в:] электронный ресурс: http://azbyka.ru/tserkov/duhovnaya_zhizn/sem_tserkovnyh_tainstv/brak/tainstvovenchanija-all.shtml 
ные свечи, обручальные кольца, венцы, подвенечный наряд, песнопения, молитвословия, чтения Евангелия, а среди дополнительных лексем: помолвка, согласие новобрачных, разрешение родителей, сватовство, родство, девичник, плач невесты, свадебный пир и пр. В свете сказанного наше исследовательское внимание будет направлено на раскрытие и осмысление основных и вспомогательных (второстепенных) семантических компонентов вышеприведенного художественного „шифра” в бунинской повести Деревня, впервые опубликованной в 1910 году и вызвавшей множество споров и противоположных отзывов.

Любопытно отметить, что венчание, или, иначе, церковный брак (причем слово „брак” славянского происхождения, от слова „брать”; брать друг друга означает „быть вместе” 12, „брачной парой” называли в старину упряжку лошадей, идущих вместе в связке), являясь основным элементом в свадебном обряде, занимало одно из важнейших мест в жизни русского народа и имело традиционную композицию, сопровождалось обрядовыми действиями и ритуалами, которые в совокупности представляли целостное праздничное театрализованное действо (возможно, отсюда выражение „сыграть свадьбу”).

В изображении свадебного обряда (в повести укладывающегося в один день, что наводит на мысль о том, что в будничном прозябании годы жизни дурновца сливаются в „один день”: настоящее лишено смысла, забыто прошлое, нет будущего) в художествнном тексте Бунина можно выделить основные этапы: сватовство, смотрины, девичник, благословение, отъезд в церковь и венчание ${ }^{13}$, причем последнее является одновременно кульминационным моментом, на котором повествование завершается, создавая впечатление „недосказанности”, как бы обрываясь („открытый финал", позволяющий читателю самому достроить и додумать сюжет, дать оценки и подвести итоги). Художник вводит в текст ритуальные предметы свадебного обряда, определяя символику ритуально-обрядового пространства. Свадьбе предшествует сватовство, во время которого Дениска с Серым приходят сватать Молодую; их поведение и речь, в отличие от грубой повседневности, заметно ритуализированы, ритуал преображает героев, припод-

12 Отныне двое соединяются в плоть едину, то есть станут одним существом душою, стремлениями, ценностями, радостями, горестями. Пройдут жизнь вместе, неразлучимо, будут любить друг друга и заботиться друг о друге. Наконец, постараются в браке своем осуществить Евангельский идеал. Цитата по: священник Константин П а р х о м е н к о, Кратко о Венчании в Православной Церкви, [в:] электронный pecypc: http://azbyka.ru/parkhomenko/kratko-o-venchanii-v-pravoslavnoj-cerkvi.html

13 М.Ю. Ф и ш, Свадебный обряд в повести И. Бунина „Деревня" (к проблеме метафизики чувственного), [в:] электронный ресурс: http://www.vestnik.vsu.ru/pdf/phylolog /2006/02/2006-02-29.pdf. 
нимая их над прозаической действительностью и перенося в обрядовое пространство ${ }^{14}$. Дениска и Серый ведут себя как герои русского эпоса и сказок, не спеша, „ладным тоном" начинают плавную обрядовую речь:

Дениска и Серый долго крестились в темный угол, потом тряхнули волосами и подняли лица. - Сват, не сват, а добрый человек! - не спеша начал Серый $[. .$.$] - Тебе нареченную дочь отдавать, мне сына женить. По доброму$ согласию, на ихнее счастье давай речь промеж себя держать. И степенно, низко поклонился 15 .

Их поведение обретает черты поведения эпических персонажей. Так, положительные герои былин, зайдя в дом, ведут себя „по-ученому”, поклоны кладут по-особому, перекрестившись на иконы, поклонившись „князю со княгинею”, „тряхнув волосами”, выступают символами молодечества и богатырской силы. Тщательно продумана писателем и каждая деталь наряда участников свадебного обряда. Достаточно вспомнить, что во время сватовства отец жениха „...подпоясан по чекменю, по кострецам красной подпояской"16. Упоминаемая такая обязательная деталь костюма, как пояс, воспринималась восточными славянами как сильнейший оберег, обладающий большой магической силой, а также защищающий от колдовства ${ }^{17}$. Молодая встречает гостей, „выходя из-за двери, от печки”, что может подчеркивать роль (печки) этого обрядового пространства, как обязательного места для невесты и как символа семейного и домашнего благополучия, как защиты, ассоциируясь с деторождением, женским миром.

Этап сватовства, сокращенный в повести до нескольких реплик, переходит в очередной - смотрины с богомольем (общая молитва родственников жениха и невесты перед иконами), во время которого Молодая закрывает, „завешивает” (прячет) свое лицо, что подразумевает установление некой границы, оберегающей невесту от окружающих и окружающих от невесты, потому что именно с этого момента начинается символический переход невесты в семейный и родовой мир жениха (от „своих” к „чужим”).

На свадьбу в Деревне пекут традиционный свадебный каравай - „ряженый пирог”, готовят кашу - символ богатства, плодородия и плодовитости; для девичника (одного из важнейших элементов сва-

14 А.А. П и с к у л и н, От Подстепья до Поморья, Елеиякий край и Выговский край - исторические регионы России 8 творчестве И.А. Бунина и М.М. Пришвина, Елец 2012, c. 104.

15 И.А. Б у н и н, Антоновские яблоки. Повести и рассказы, Москва 1975, с. 149.

16 Там же.

17 В.П. А н и к и н, Календарная и свадебная поэзия, Москва 1970, с. 120. 
дебного обряда, восходящего к древнему обряду инициации, при котором девушка сначала как бы умирала, чтобы потом возродиться в новом статусе $\left.{ }^{18}\right)$ достают елку, специально „сберегаемую в погребе, переходившую с девишника на девишник" ${ }^{\prime 19}$. Елка или другое деревце в общерусской свадебной традиции символизирует девичество, девичью волю, с которой прощается невеста. „Маленькое зеленое деревцо, убранное кумачными лоскутками, стояло на столе, простирая ветки над тусклой жестяной лампочкой" 20 . Неотъемлемой частью данного этапа свадьбы был плач невесты, имевший в свадебной традиции обрядовый характер (традиция слезного причитания с древней поры поддерживалась обычаем посредством нарочитого выражения горя ставить себя вне опасных действий воображаемых покровителей семьи - таинственных сил судьбы ${ }^{21}$ ). Согласно ритуалу, игрицы поют „старинную величальную песню”, на которую невеста „должна была ответить [...] громким плачем и причитаниями" (в величальной песне упоминается девичник, а в сиротской - растопленная баня, мытье невесты в бане как неотъемлемая часть свадебного обряда 22 ). Но Молодая отказывается от участия в пении, а в ее молчании угадывается обреченность.

Анализируя эмоциональную атмосферу в литературном пространстве, нельзя оставить без внимания того, что в описании происходящего, представленного остраненно - через восприятие Кузьмы, проступают и как бы смешиваются зрительные („серая темнота, клубы пара, тусклая жестяная лампочка, лиц не видно, черные сырые стены, землистое лицо Дениски”) и звуковые („Однодворка [...] зажгла в людской лампочку, [...] и, чтобы нарушить неловкость, высоко и резко запела", „Домашка, хромая девка с темным, злым и умным лицом, с черными острыми глазами и черными сросшимися бровями, затянула грубым и сильным голосом старинную величальную песню") коды в художественном пространстве, что, в свою очередь, (в)скрывает тонкие смысловые аллюзии: теснота, темнота, звуковая дисгармония вызывают ощущение антисвадьбы - похорон, что созвучно бунинскому "сочетанию несочетаемого”: смерти (девушки) и рождения (жены), свадьбы и похорон, трагического и фарсового.

Ощущение „неправильности” (неловкости, ужаса) чувствуется и в самой завязке трагичной сюжетной ситуации, когда Тихон Ильич Красов, изводясь в горьких думах не только о пустоте своей жизни, но

\footnotetext{
18 А.А. П и с к у л и н, указ. соч., с. 106.

19 И.А. Б у н и н, указ. соч., с. 152.

20 Там же.

21 В.П. А н и к и н, указ. соч., с. 82.

${ }^{22}$ А.А. П и с к у л и н, указ. соч., с. 109.
} 
и о содеянном надругательстве над Молодой, одновременно готовя себя к вечной жизни, решает „за грех свой сотворить благое": выдать Молодую за Дениску Серого. Таким образом Молодая (чье прозвище соотносит героиню с будущим) становится для Тихона Ильича своеобразным путем спасения, избавления от грехов. Молодой отводится роль жертвы, принесенной Тихоном ради надежды на спасение от гибели, на которую она обречена ${ }^{23}$, что в свою очередь позволяет обнаружить в художественном пространстве повести мотив жертвоприношения. Весьма вероятно, что опосредованное сравнение молодой женщины с коровой как традиционно жертвенным животным в начале повести служит признаком ее готовности принести себя в жертву:

Носят дурновские бабы „рога” на голове: как только из-под венца, косы кладутся на макушке, накрываются платком и образуют нечто дикое, коровье. Носят старинные темно-лиловые поневы с позументом, белый передник вроде сарафана и лапти. Но Молодая, - за ней так и осталась эта кличка, - была и в этом наряде хороша 24 .

Некие отголоски темы жертвоприношения звучат и в сцене приготовления свиньи к свадебному пиру, изображенной как древний языческий ритуал:

На бугре, в синеватых сумерках, оранжевым пламенем пылала солома, которой завалили убитую свинью. Вокруг пламени, поджидая добычи, сидели овчарки, и белые морды их, груди были шелковисто-розовы. Серый, утопая в снегу, бегал, поправлял костер, замахивался на овчарок. Полы зипуна он развернул и поднял, заткнул за пояс, шапку все сдвигал на затылок кистью правой руки, в которой блестел нож. Бегло и ярко озаряемый то с той, то с другой стороны, Серый кидал на снег большую пляшущую тень - тень язычника ${ }^{25}$.

Свинья становится знаком жертвенности самой невесты, которая не может отказаться от свадьбы - „расход уж начали", то есть зарезали свинью, „теперь поздно”, „уж и так страму не оберешься [...] Ай не знают все, на чьи деньги пировать-то будем?", тем самым отвечая на предложение Кузьмы разорвать союз, обрекающий будущих мужа и жену на взаимную ненависть. Заклание свиньи трагическим отголоском перекликается с закланием самой Молодой как воплощением поруганной красоты, добра, затаенной душевности. Думается, что в мотиве оскверненной красоты, который проходит через все творчество Бунина, реализуется представление о нарушении основ мироустройства, ощущаемого как перманентное состояние жизни.

${ }^{23}$ М.Ю. Ф и ш, указ. соч.

24 И.А. Б у н и н, указ. соч., с. 54.

25 Там же, с. 151. 
Повесть венчает образ страшной стихии - „непроглядная вьюга”, закрывающая „смелый свет”, „гул ветра". Кажется, что с этим бесконечным смерчем сливается такое же, никем не управляемое, несущееся в „буйную темную муть” движение лошадей, увозящих в никуда исплаканную, полумертвую Молодую. С каждой строкой последних страниц повести усиливается настроение безысходности, смирения и покорности судьбе перед злыми силами, угнетающими человека:

На невесте и шубку и голубое платье завернули на голову [...]. Голова ее, убранная венком бумажных цветов, была закутана шалями, подшальниками. Она так ослабела от слез, что как во сне видела темные фигуры среди вьюги, слышала шум ее, говор, праздничный звон колокольцев. Лошади прижимали уши, воротили морды от снежного ветра, ветер разносил говор, крик, слепил глаза, белил усы, бороды, шапки, и проезжие с трудом узнавали друг друга в тумане и сумраке26.

И обряд венчания изображен в удручающих трагических красках, усиливающих настроение отчаянности. Ужасом веет от описания темной, холодной и угарной церкви, в которой сгрудившаяся толпа неграмотных мужиков слушает непонятное, но торопливо строгое бормотание священника. „И рука Молодой, казавшейся в венце еще красивей и мертвее, дрожала, и воск тающей свечи капал на оборки ее голубого платья". Все в описываемых деталях (мертвая в свете, рука Молодой, тающая свеча) напоминает о смерти, вызывающей чувство гложущей тоски. А самые последние строки повести создают картину разгула темных сил, шабаша ведьм. В финальном символическом пейзаже звучит погребально колокольный звон: „Когда возвращались из церкви, вьюга пуще разгулялась, а одна из баб выла в санях волчьим голосом" 27.

Подытоживая, можно сказать, что художественному концепту венчания в анализируемом литературном тексте свойственно индивидуально-авторское наполнение - (бунинское) „сочетание несочетаемого” или, заимствуя слова Осипа Мандельштама, „праздничная смерть”. Венчание как величайшее таинство, место особой встречи между Богом и человеком, рождение новой малой церкви в поэтическом пространстве Деревни обнаруживает родство с крайней степенью небытия - со смертью, стоящей в том же онтологическом ряду, вписывая человека в круговорот вечной жизни, приобщая к тайне бытия. Кроме того, символический образ Молодой в этой страшной, нечистой жизни представляется словно икона с лампадкой в курной избе, что может сопрягаться, в свою очередь, с идеей кенозиса. Трагизм образа Молодой

\footnotetext{
26 Там же, с. 154.

27 И.А. Б у н и н, указ. соч., с. 156.
} 
- в жажде самоуничижения (кенозис), самоумаления, смирения ради спасения людей: если Сын Божий Единородный так смирился, то как же нам, окаянным грешникам, не смиряться?28 Кенозис, таким образом, необходим, с одной стороны, для осознания того, что причина кризиса в современной Бунину России кроется в безверии, изживании Духовности, „смерти Бога” (а тогда и непонимании иконы), а с другой стороны, нужен для осуществления главного упования христианства, достижения Царства Божия „на земле, яко на небе”, для того, чтобы человек смог осуществить свою главную задачу - „теозис" (обожествление), став проводником Божественных энергий в мире.

\section{Библиография}

А н и к и н В.П., Календарная и свадебная поэзия, Москва 1970.

А с к о л ь д о в С.А., Кониепт и слово, [в:] Русская словесность. От Теории словесности к структуре текста. Антология, ред. В.П. Нерознак, Москва 1997.

Б а х т и н М.М., Проблема речевых жанров. Проблема текста, [в:] его же, Собрание сочинений $в 5$ томах, т. 5, Москва 1996.

Б у н и н И.А., Антоновские яблоки. Повести и рассказы, Москва 1975.

Г а в р и л о в Д.А., Н а г о в и ц ы н А.Е., Боги славян. Язычество, Традиция, Москва 2002.

Л и х а ч е в Д.С., Конщептосфера русского языка, [в:] Русская словесность. От Теории словесности к структуре текста. Антология, ред. В.П. Нерознак, Москва 1997.

П а р х о м е н к о К. (протоиерей), Кратко о Венчании в Православной Церкви, [в:] электронный ресурс: http://azbyka.ru/parkhomenko/kratko-o-venchanii-v-pravoslavnojcerkvi.html

П и с к у л и н А.А., От Подстепья до Поморья, Елецикий край и Выговский край - исторические регионы России в творчестве И.А. Бунина и М.М. Пришвина, Елец 2012.

Р а с с е л Б., История западной философии, т. 1, Москва 1993.

С т е п а н о в Ю.С., Константы. Словарь русской культуры. Опыт исследования, Москва 1997.

Т а у ш е в А.П. (Архиепископ А в е р к и й), Апостольские послания, [в:] электронный pecypc: http://neopalimovsky.ortox.ru/data/documents/08-Apostol-katkurs.pdf.

Ф и ш М.Ю., Свадебный обряд в повести И. Бунина „Деревня" (к проблеме метафизики чувственного), [в:] электронный ресурс: http://www.vestnik.vsu.ru/pdf/phylolog /2006/02/2006-02-29.pdf.

Х у л а п В. (протоиерей), Таинство Венчания, [в:] электронный ресурс: http://azbyka.ru/ tserkov/duhovnaya_zhizn/sem_tserkovnyh_tainstv/brak/tainstvo-venchanija-all.shtml

${ }_{28}$ Архиепископ А в е р к и й (Т а у ш е в), Апостольские послания, [в:] электронный ресурс: http://neopalimovsky.ortox.ru/data/documents/08-Apostol-katkurs.pdf. 
